\title{
Segregation and fertility in Mus musculus domesticus (wild mice) heterozygous for the $\mathrm{Rb}(4.12)$ translocation
}

\author{
M.-C. VIROUX \& V. BAUCHAU* \\ Unité de Biologie Animale, Université Catholique de Louvain, Croix du Sud 5, 1348, Louvain-la-Neuve, Belgium
}

\begin{abstract}
Analysis of the progeny of wild mice heterozygous for the $\mathrm{Rb}(4.12)$ shows that fertility and segregation are normal. This study, and others with similar results, suggests that our view of the chromosomal evolution of the house mouse should be revised.
\end{abstract}

Keywords: fertility, Mus musculus domesticus, Robertsonian translocation, segregation.

\section{Introduction}

Robertsonian $(\mathrm{Rb})$ translocations are chromosomal mutations that result from the fusion of two acrocentric chromosomes, thus making a single metacentric one. The carriers therefore show a reduced chromosomal number. A mis-disjunction of the chromosomes at the first meiotic division in heterozygotes can lead to the formation of aneuploid gametes. These aneuploid gametes are fertile, but the trisomic and monosomic embryos that they form are lethal (Gropp \& Winking, 1981).

Among natural populations, Robertsonian translocations could reduce the fertility of the heterozygous carriers and one should observe a limited spread and fixation of the fusions. However, these fusions are widely distributed among natural populations of Mus musculus domesticus in Western Europe and North Africa (Winking et al., 1988; Bauchau, 1990). We are thus confronted with a paradox.

There may be some compensation mechanisms that act in favour of dispersion and fixation of the fusions. A segregation distortion in favour of the Robertsonian chromosomes is a likely candidate. Segregation distortion consists of a preferential transmission of one allele (or a chromosome form) in relation to the other in one of the gametes of the heterozygotes. It is suggested in females that one of the chromosomal forms (e.g. the metacentric) could be preferentially distributed into the egg, and the other into the polar body, during the first meiotic division (Gropp \& Winking, 1981). Segregation distortion could have important consequences

*Correspondence: Unité de Biométrie, Université Catholique de Louvain, Croix du Sud 2 bte 16, 1348 Louvain-la-Neuve, Belgium. for the populations, leading to the fixation of the chromosomal form, especially in small populations (Bush et al., 1977; Hedrick, 1981).

In this paper, we investigate segregation of chromosomes and fertility of wild mice heterozygous for the Robertsonian translocation $\mathrm{Rb}(4.12)$, which is present in an intensively studied Belgium population (Hübner, 1988; Hübner \& Koulischer, 1990; Bauchau et al., 1990). This fusion is also widely spread in many natural populations in Europe, from Belgium to Northern Italy. A phylogenetic analysis (Bauchau, 1990) suggests that this fusion has appeared only once and subsequently spread over a very large area, possibly because of selective forces (see also Corti et al., 1986; Winking et al., 1988).

On the basis of our results, we question the role that chromosomal non-disjunction and segregation distortion could have on the spread and fixation of Robertsonian fusions in wild mice populations.

\section{Materials and methods}

Crosses were made of wild mice caught in Belgium, and their laboratory-bred progeny. All mice were kept in an animal house under constant conditions of temperature $\left(20^{\circ} \mathrm{C}\right)$, humidity, and light cycle $(12 / 12 \mathrm{~h})$, in $27 \times 21 \times 14 \mathrm{~cm}$ cages, provided with food (U.A.R. A 03) and water ad libitum. Crosses were performed between $\mathrm{Rb}(4.12)$ heterozygotes whose chromosomal number was $2 n=39$ and normal homozygotes $(2 n=40)$. The karyotypes of the progeny of each pair were analysed by lymphocyte culture, according to the technique described by Davisson \& Akeson (1987). G-banding was performed following a method based on Evans (1987). 
Segregation was assessed by counting the numbers of young carrying the translocation in the progeny of the pairs with one heterozygous and one normal parent; the heterozygous parent was either the female $\left(\$ 39 \times \sigma^{2} 40\right)$ or the male $\left(\$ 40 \times \sigma^{39}\right)$. We studied the fertility by comparing the litter size at weaning of the pairs $39 \times 40$ with the control pairs, for which the two parents were homozygous $\left(\$ 40 \times{ }^{4} 40\right.$ or $\$ 38 \times \sigma^{4} 40$ or $\$ 40 \times \circlearrowleft 38$ ). No difference in the litter size was detected among caryotypes within this control group $(F=0.22 ; P>0.5)$.

\section{Results}

The progeny analysed came from $23(\% 39 \times 840)$ crosses and $20(\$ 40 \times \% 39)$ crosses. A total of 116 litters were born, representing 601 mice among which 292 randomly chosen individuals were karyotyped.

No segregation distortion was found (Table 1), either for females $\left(\chi^{2}=0.053 ; P>0.1\right)$ or males $\left(\chi^{2}=0.203\right.$; $P>0.1)$ heterozygous for the Robertsonian translocation $\mathrm{Rb}(4.12)$. Similarly, segregation ratio did not differ from the expected 50:50 ratio (percentage of heterozygotes: 48.6 per cent; $\chi^{2}=0.219 ; P>0.1$ ) when data were pooled over all matings.

We found little variation in the mean litter size between the different mating types (Table 2). The litter size is slightly less for the controls $(5.03 \pm 0.23$; mean \pm St. Er.) than in the ' $39 \times 40$ ' group $(5.24 \pm$ 0.22 ), but this difference was not significant. Likewise, when we compared the litter size of the groups for which the father is heterozygous to the groups whose mother was heterozygous, we did not find any significant differences (Table 2).

\section{Discussion}

We did not detect any distortion of segregation of chromosomes in the progeny of wild mice heterozygous for the Robertsonian translocation $\mathrm{Rb}(4.12)$. Our sample size, although relatively large, did not allow us to detect a segregation rate less than 7 per cent, which could still have significant effects on the populations (Hedrick, 1981).

Few studies have been performed to date on segregation distortion for Robertsonian fusion, and most of them were not performed on pure wild mice. Unequal transmission of the metacentric was reported by Harris et al. (1986) and by Gropp \& Winking (1981). These reports must be considered with caution however since these authors used mice with a peculiar genetic background, either hybrids between wild and laboratory mice (Gropp \& Winking, 1981) or wild mice from Peru, with unusual characteristics (Harris et al., 1986). The only data on pure wild European mice are given by Britton-Davidian et al. (1990) and Nancé et al.

Table 1 Segregation ratio $(p)$ of the chromosomes in the progeny of crosses between heterozygous $\mathrm{Rb}(4.12)$ and karyotypically normal mice

\begin{tabular}{|c|c|c|c|c|}
\hline Parents & $\begin{array}{l}2 n=39 \\
\text { descendants }\end{array}$ & $\begin{array}{l}2 n=40 \\
\text { descendants }\end{array}$ & Total & $\begin{array}{l}95 \% \text { confidence } \\
\text { interval }\end{array}$ \\
\hline$\$ 39 \times 0740$ & $\begin{array}{l}83 \\
(49.1 \%)\end{array}$ & $\begin{array}{l}86 \\
(50.9 \%)\end{array}$ & 169 & $0.42<p<0.57$ \\
\hline$\$ 40 \times 039$ & $\begin{array}{l}59 \\
(48.0 \%)\end{array}$ & $\begin{array}{l}64 \\
(52.0 \%)\end{array}$ & 123 & $0.39<p<0.57$ \\
\hline Total & $\begin{array}{l}142 \\
(48.6 \%)\end{array}$ & $\begin{array}{l}150 \\
(51.4 \%)\end{array}$ & 292 & $0.43<p<0.54$ \\
\hline
\end{tabular}

Table 2 Litter size analysis for crosses involving karyotypically different mice

\begin{tabular}{llll}
\hline Parents & $\begin{array}{l}\text { Mean litter size } \\
\pm \text { S.E. }\end{array}$ & $\begin{array}{l}\text { Number } \\
\text { of litters }\end{array}$ & F-test \\
\hline Control & $5.03 \pm 0.23$ & 32 & $F=0.29$ \\
$\$ 39 \times 0^{\circ} 40+\$ 40 \times 0^{3} 39$ & $5.24 \pm 0.22$ & 84 & $P>0.5$ \\
\hline$\$ 39 \times 0^{\circ} 40$ & $5.28 \pm 0.26$ & 47 & $F=0.04$ \\
$\$ 40 \times 0^{\circ 39}$ & $5.19 \pm 0.36$ & 37 & $P>0.5$ \\
\hline
\end{tabular}


(1990). They did not find any deviation from the expected values in the transmission of the $R b(16.17)$ and $\mathrm{Rb}(3.8)$ translocations, respectively.

We have observed that fertility appears to be unaffected in $\mathrm{Rb}(4.12)$ heterozygotes. Different studies have proved that single or multiple heterozygotes effectively show an increased risk of producing aneuploid gametes. Cattanach \& Moseley (1973), Tettenborn \& Gropp (1970) and Gropp \& Winking (1981) studied aneuploidy rates in the gametes of single heterozygotes for different $\mathrm{Rb}$ translocations introduced in laboratory strains and found that nondisjunction rates differed from one fusion to another, ranging up to 28 per cent. A rate of 8 per cent was found by Gropp and Winking (1981) for the $\mathrm{Rb}(4.12)$ in hybrid mice. In wild mice from Peru, Harris et al. (1986) observed non-disjunction rates of 10 per cent in males and from 12 to 16 per cent in females heterozygous for the $\mathrm{Rb}(9.12)$. They also found an increased proportion of pre-implantation losses in these heterozygotes versus karyotypically normal mice ( 21.3 per cent versus 2.9 per cent). But these authors did not find any significant reduction in the litter size of $R b(9.12)$ heterozygous females. This difference could be explained by the effects of lower sample size and higher intra-class variability in litter size analysis compared to gamete analysis.

Data from wild European mice are given by BrittonDavidian et al. (1990) who have not found and significant reduction in the litter size of $\mathrm{Rb}(16.17)$ heterozygotes versus the karyotypically normal controls. Winking et al. (1988) similarly reported a very low rate of non-disjunction in a wild heterozygous mouse from Zadar.

In summary, it appears that data from pure wild European mice cannot be compared with data from other genetic backgrounds. We conclude that distortion of segregation has not been detected so far in wild European Mus musculus domesticus populations. However, a small rate of distortion (e.g. $<0.05$ ) is difficult to detect because of the large sample sizes needed but could still have an important influence on the evolution of the fusions (Hedrick, 1981). Proof of a reduced fertility in wild heterozygotes for one or few independent fusions had so far not been reported either but the larger the number of fusions, the more the fertility can be affected (Redi \& Capanna, 1988), and the fitness of heterozygotes for several fusions can be more seriously decreased. Furthermore, in hybrid zones between populations with common acrocentrics involved in different fusions, the fertility of heterozygotes with arm homologies is reduced (Capanna, 1982).

In addition to the segregation distortion, other mechanisms can be assumed to act to compensate for the possible reduced fertility. The social structure of the mouse, organised in demes with restriced intergroup gene flow (de Fries \& McClearn, 1972), is thought to play an important role in the fixation of the fusions, through the effects of inbreeding. Genetic drift in small populations is also thought to be a factor leading to the fixation of fusions (Bush et al., 1977; Hedrick, 1981). The demic structure of house mouse populations has, however, been seriously questioned (Berry, 1986). An experimental introduction of $\mathrm{Rb}$ mice in a karyotypically normal population has shown that $\mathrm{Rb}$ chromosomes can spread very rapidly in a population even though heterozygotes for three $\mathrm{Rb}$ metacentrics must have occurred (Berry et al., 1990). According to his phylogenetic study of $\mathrm{Rb}$ populations in Europe, Bauchau (1990) suggests that most of the Robertsonian populations have non-independent origins and that chromosomal flow between these populations is an important process, contrary to what has been understood until now (see also Corti et al., 1986; Winking et al 1988).

It thus appears that the spread of $\mathrm{Rb}$ chromosomes in the population may not be limited by impaired fertility in heterozygotes, and that segregation distortion and demic structure may not play a significant role. Other selective factors, if any, remain to be explored.

\section{Acknowledgements}

VB is a senior research scientist at the FNRS. This study was supported by EEC grant number $\mathrm{SC} 1 *$ 0272-C.

\section{References}

BAUCHAU, v. 1990. Phylogenetic analysis of the distribution of chromosomal races of Mus musculus domesticus Rutty in Europe. Biol. J. Linn. Soc., 41, 171-192.

BAUCHAU, V., SMETS, S., VIROUX, M-C., NOOTENS, D. AND DE CARITAT, A.-K. 1990. Robertsonian translocations in free-living populations of the House Mouse in Belgium. Biol. J. Linn. Soc., 41, 193-201.

BERRY, R. J. 1986. Genetical processes in wild mouse populations. Past myth and present knowledge. Curr. Top. Microbiol. Immuno., 127, 86-94.

BERRY, R. J., TRIGGS, G. S., BAUCHAU, V., JONES, C. S. AND SCRIVEN, P., 1990. Gene flow and hybridization following introduction of Mus domesticus into an established population. Biol. J. Linn. Soc., 41, 279-283.

BRITTON-DAVIDIAN, J., SONJAYA, H., CATALAN, J. AND CATTANEOBERREBI, G. 1990. Robertsonian heterozygosity in wild mice: fertility and transmission rates in $\mathrm{Rb}(16.17)$ translocation heterozygous. Genetica, 80, 171-174. 
BUSH, G. L., CASE, S. M., WILSON, A. C. AND PATTON, J. L. 1977. Rapid speciation and chromosomal evolution in mammals. Proc. Natl. Acad. Sci., U.S.A., 74, 392-394.

CAPANNA, E. 1982. Robertsonian numerical variation and animal speciation: Mus musculus, an emblematic model. In: Barrigozi, C. (ed.) Mechanisms of Speciation; Alan R. Liss, New York, pp. 155-177.

CATtanaCh, B. M. AND moseley, H. 1973. Nondisjunction and reduced fertility caused by the tobacco mouse metacentric chromosomes. Cytogenet. Cell. Genet., 12, 264-287.

CORTI, M., CAPANNA, E. AND ESTABROOK, G. F. 1986. Microevolutionary sequences in house mouse chromosomal speciation. Syst. Zool., 35, 163-175.

DAVISSON, M. T, AND AKESON, E. C. 1987. An improved method for preparing G-banded chromosomes from mouse peripheral blood. Cytogenet. Cell Genet., 45, 70-74.

DE FRIES, J. C. AND MC CLEARN, G. E. 1972. Behavioural genetics and the fine structure of mouse populations: a study in microevolution. Evol. Biol., 5, 279-291.

EVANS, E. P. 1987. Karyotyping and sexing of gametes, embryos and fetuses and in situ hybridization of chromosomes. In: Monk, M., (ed.) Mammalian Development : a Practical Approach, IRL Press, Oxford, pp. 93-114.

GROPP, A., AND WINKING, H. 1981. Robertsonian translocations : cytology, meiosis, segregation patterns and biological consequences of heterozygosity. Symp. Zool. Soc. London, 47 , 141-181.
haRRIS, M. J., WALlaCE, M. E. AND EVANS, E. P. 1986. Aneuploidy in the embryonic progeny of females heterozygous for the Robertsonian chromosome $\mathrm{Rb}(9: 12)$ in genetically-wild Peru-coppock mice (Mus musculus). J. Reprod. Fert., 76 193-203.

HEDRICK, P. W. 1981. The establishment of chromosomal variants. Evolution, 35, 322-332.

HÜBNER, R., 1988. Populations Robertsoniennes chez la souris 'sauvage' (Mus domesticus Rutty 1772) en Belgique. Ann. Soc. Roy. Zool. Belg., 118, 69-75.

HÜBNER, R, AND KOULISCHER, L., 1990. Cytogenetic studies on wild house mice from Belgium. Genetica, 80, 93-100.

NANCĖ, V., VANLERBERGHE, F., NIELSEN, J. T., BONHOMME, F. AND BRITTON-DAVIDIAN, J., 1990. Chromosomal introgression in house mice from the hybrid zone between $M . m$. domesticus and M. m. musculus in Denmark. Biol. J. Linn. Soc., 41, 215-227.

REDI, C. A. AND CAPANNA, E. 1988. Robertsonian heterozygotes in the house mouse and the fate of their germ cells. In: Daniel, A. (ed) The Cytogenetics of Mammalian Autosomal Rearrangements; Alan R. Liss, Inc., New York, pp. 315-359.

TETTENBORN, U. AND GROPP, A. 1970. Meiotic non-disjunction and mouse hybrids. Cytogenetics, 9, 272-283.

WINKING, H., DULIC, B. AND BULFIELD, G. 1988. Robertsonian karyotype variation in the European house mouse $M u s$ musculus. Z. Säugetierkunde, 53, 148-181. 